\title{
SH3BP2 wt Allele
}

National Cancer Institute

\section{Source}

National Cancer Institute. SH3BP2 wt Allele. NCI Thesaurus. Code C101438.

Human SH3BP2 wild-type allele is located 4p16.3 and is approximately $48 \mathrm{~kb}$ in length.

This allele, which encodes $\mathrm{SH} 3$ domain-binding protein 2 , is involved in the modulation of signaling. Mutation of the gene is associated with cherubism. 